\title{
PEMBELAJARAN MELALUI BRAIN BASED LEARNING DALAM PENDIDIKAN ANAK USIA DINI
}

\author{
Chamidiyah \\ Tasamuh Institute, Jawa Tengah, Indonesia. \\ nurulchamidiyah@yahoo.com
}

\begin{abstract}
Abstrak
Artikel ini bertujuan untuk memberikan gambaran serta menganalisis model pembelajaran melalui "brain based learning" dalam pendidikan anak usia dini. Penelitian ini berbentuk penelitian kepustakaan (library research) dengan menggunakan metode pendekatan deskriptif analisis terhadap tema-tema Brain based learning yang merupakan model pembelajaran yang sangat tepat diterapkan dalam pendidikan anak usia dini. Pembelajaran dan pengajaran Brain based mengacu pada pemberdayaan potensi otak. Ada tiga strategi dalam brain based learning. Pertama, menciptakan lingkungan belajar yang menantang kemampuan berfikir siswa. Kedua, menciptakan lingkungan pembelajaran yang menyenangkan. Ketiga, Menciptakan situasi yang aktif dan bermakna bagi siswa (active learning). Pada periode anak usia dini seluruh aspek perkembangan anak sangat peka, sehingga masa ini perlu dikelola secara optimal melalui upaya berbagai stimulasi yang mendukung pertumbuhan dan perkembangan anak. Dengan mengetahui perkembangan anak, brain based learning sesuai diterapkan dalam pengajaran dalam pendidikan anak usia dini.
\end{abstract}

Kata kunci: pembelajaran, pendidikan, anak usia dini, brain based learning 


\begin{abstract}
BRAIN BASED LEARNING IN CHILDHOOD EDUCATION. This article aims to provide an overview of the learning through brain based learning in childhood education. This study is library research by using analytical descriptive approach to Brain based learning themes as a learning model actually has its own interesting bargaining power to be applied in the learning process ecpecially in the Early Childhood Education. Brain-based teaching and learning offers a concept to create learning oriented to the empowerment of student's brain potential. There are three strategies that can be developed in implementation of brain based learning. First, create a learning environment that challenges students' thinking ability. Second, create a fun learning environment. Third, create a situation of active and meaningful for students. By knowing the brain development in children, parents and teachers can apply the appropriate education and teaching to the children.
\end{abstract}

Keywords: learning, early childhood education, brain based learning

\title{
A. Pendahuluan
}

Belajar adalah suatu proses yang kompleks yang terjadi pada semua orang dan berlangsung seumur hidup, sejak dia bayi sampai ke liang lahat (Sardiman, 2001: 1). Proses belajar selalu eksis dalam proses kehidupan dari awal hingga akhir. Salah satu pertanda seseorang telah belajar sesuatu adalah adanya perubahan tingkah laku dalam dirinya. Perubahan tingkah laku tersebut menyangkut perubahan bersikap pengetahuan (kognitif) dan keterampilan (psikomotorik) maupun yang menyangkut nilai dan sikap (afektif). Menurut Winkel belajar didefinisikan sebagai suatu aktifitas mental atau psikis yang berlangsung dalam interaksi aktif dengan lingkungan, keterampilan dan nilai-nilai sikap yang yang bersifat relatif konstan dan berbekas. Sedangkan pembelajaran adalah serangkaian yang dirancang untuk memungkinkan terjadinya proses belajar pada siswa. Pembelajaran mengacu pada segala kegiatan yang berpengaruh langsung terhadap proses belajar siswa dan pembelajaran harus menghasilkan. Belajar merupakan konsep yang tidak dapat dihilangkan dalam proses belajar mengajar/pembelajaran (Faturrohman, 2012: 9).

Proses belajar mengajar merupakan inti dari proses formal di 
sekolah yang di dalamnya terjadi interaksi antara berbagai komponen di sekolah, komponen tersebut dikelompokkan atas tiga kategori utama yaitu guru, materi, dan siswa. Interaksi antara tiga komponen utama melibatkan sarana dan prasarana seperti metode, media, lingkungan tempat belajar sehinggga tercipta situasi belajar mengajar yang memungkinkan tercapainya tujuan yang telah direncanakan, dengan demikian guru memegang peranan penting dalam proses belajar mengajar (Fathurrahman, 2012: 37).

Banyak inovasi yang telah dilakukan dalam dunia pendidikan dalam meningkatkan mutu pendidikan khususnya siswa, baik yang berkaitan dengan kurikulum, bahan ajar, media pembelajaran, model pembelajaran dan lain-lain. Brain based learning atau pembelajaran berbasis otak sebagai salah satu model pembelajaran sebenarnya mempunyai daya tawar tersendiri yang menarik untuk dikemukaan terlebih jika penerapannya diterapkan pada Pendidikan Anak Usia Dini.

Dalam pelaksanaannya, kajian ini menggunakan jenis penelitian telaah kepustakaan/library research yang menggunakan pendekatan deskriptif analisis. Penulis memusatkan fokus pembahasan pada literatur-literatur yang mengulas tentang tema brain based learning. Dengan kajian ini diharapkan mampu memberikan gambaran yang jelas terhadap proses pembelajaran dengan menggunakan model brain based learning.

\section{B. Pembahasan}

\section{Pendidikan Anak Usia Dini}

Berdasarkan Undang-undang No. 20 Tahun 2003 tentang Sistem pendidikan Nasional berkaitan dengan Pendidikan Anak Usia Dini tertulis pada pasal 28 ayat 1 yang berbunyi” Pendidikan Anak Usia Dini diselenggarakan bagi anak sejak lahir sampai dengan enam tahun dan bukan merupakan prasyarat untuk mengikuti pendidikan dasar" "Usia dini merupakan masa emas perkembangan (golden age) yang keberhasilannya sangat menentukan kualitas anak di masa dewasanya" (Megawangi, 2011: 18). Maria Montesori menyebut masa ini dengan istilah "periode kepekaan (sensitive period)” (Hurlock, 1978: 13). Pada periode tersebut seluruh aspek 
perkembangan anak sangat peka, sehingga masa ini perlu dikelola secara optimal melalui upaya berbagai stimulasi yang mendukung pertumbuhan dan perkembangan anak. Agar para orang tua atau guru dapat mengenali berbagai kecerdasan yang dimiliki seorang anak, sebaiknya anak dibebaskan untuk memilih jenis kegiatan yang disenangi. Dengan demikian, anak maupun orang tua dan guru dapat mengidentifikasi kombinasi antara kecerdasan anak yang cenderung menonjol atau kurang maupun jenis-jenis kecerdasan yang tampak kurang berkembang (Ahmad, 2014: 2).

Dalam mengembangkan kecerdasan anak usia dini, kegiatan pendidikan anak usia dini hendaknya memperhatikan 9 kemampuan belajar anak yang meliputi:

1. Kecerdasan linguistic (linguistic intelligence) yang dapat berkembang bila dirangsang melalui berbicara, mendengarkan, membaca, menulis, berdiskusi dan bercerita.

2. Kecerdasan logika-matematika (logico mathematical intelligence) yang dapat dirangsang melalui kegiatan menghitung, membedakan bentuk, menganalisis data dan bermain dengan benda-benda.

3. Kecerdasan visual-spasial (visual-spatial intelligence) yang dapat dirangsang melalui bermain balok-balok. Dan bentukbentuk geometri melengkapi puzzle, menggambar, melukis, menonton film maupun bermaian dengan daya khayal (imajinasi)

4. Kecerdasan musical (musical/thythmic intelligence) yang dapat dirangsang melalui irama, nada, birama, berbagai bunyi dan bertepuk tangan.

5. Kecerdasan kinestetik (bodily/linesthetic intelligence) yang dapat dirangsang melalui gerakan, tarian, olahraga dan terutama digerakan tubuh.

6. Kecerdasan naturalis (naturalist intelligence) yaitu mencintai keindahan alam, yang dapat dirangsang melalui pengamatan lingkungan, bercocok tanam, memelihara binatang, termasuk mengamati fenomena alam seperti hujan, angin, pelangi, siang malam, panas dingin, bulan matahari.

7. Kecerdasan interpersonal (interpersonal intelligence) yaitu kemampuan untuk melakukan hubungan antar manusia 
(berkawan) yang dapat dirangsang melalui bermain bersama teman, bekerjasama, bermain peran, dan memecahkan masalah, serta menyelesaikan konflik.

8. Kecerdasan intrapersonal (intrapersonal intelligence) yaitu kemampuan memahami diri sendiri yang dapat dirangsang melalui pengembangan konsep diri, harga diri, mengenal diri sendiri, termasuk kontrol diri dan disiplin.

9. Kecerdasan spiritual (spiritual intelligence) yaitu kemampuan mengenal dan mencintai Tuhan, yang dapatdirangsang melalui penanaman nilai-nilai moral dan agama (Direktorat Pendidikan Usia Dini Direktorat Jenderal Pendidikan Non Formal dan Informal Departemen Pendidikan Nasional, 2009: 57).

Menurut Damanhuri Rosadi dalam buku mengembangkan kecerdasan spiritual anak (Muhammad Azzet), mengatakan kecerdasan anak yang utuh dimulai sejak anak dalam kandungan dan memasuki masa keemasan atau golden age pada usia 0-6 tahun. Masa tersebut ditandai oleh berkembangnya jumlah dan fungsi sel-sel saraf otak anak. Fungsionalisasi sel-sel saraf tersebut akan berjalan dengan optimal manakala ada upaya sinergi antara emosi, psikis, intelegensi.

\section{Perkembangan Otak Pada Anak Usia Dini}

Kegiatan pendidikan adalah serangkaian proses pendidikan yang dilakukan secara terencana untuk mencapai hasil belajar. Pendidikan anak usia dini adalah suatu upaya pembinaan yang ditujukan kepada anak sejak usia dini yang dilakukan melalui pemberian rangsangan pendidikan untuk membantu pertumbuhan dan perkembangan jasmani dan rohani agar anak memiliki kesiapan dalam memasuki pendidikan dasar dan kehidupan tahap berikutnya sedangkan pengembangan anak usia dini adalah upaya yang dilakukan oleh masyarakat dan atau pemerintah untuk membantu anak usia dini dalam mengembangkan potensinya secara holistic baik aspek pendidikan, gizi, kesehatan maupun psikososialnya (Widarmi, 2008: 1.4).

Istilah perkembangan acapkali disandingkan dengan pertumbuhan dalam beberapa kesempatan terkadang justru kedua istilah ini menjadi rancu dan terkesan tumpang-tindih. 
Tumbuh menurut Patmonodewo berarti bertambah dalam ukuran. Pertumbuhan tidak hanya di pengaruhi oleh jumlah dan macam makanan yang dikonsumsi tubuh tetapi juga dipengaruhi oleh beberapa hal seperti psikologis, perkembangan sosial, proses sosial atau hubungan antara pengasuh dan anak yang baik. Berbeda halnya dengan perkembangan yang diartikan sebagai perubahan dalam kompleksitas dan fungsinya. Lebih rinci ia menjelaskan bahwa perkembangan kognitif dan sosial anak dipengaruhi oleh pertumbuhan sel otak dan perkembangan hubungan antar sel otak, oleh karenanya meskipun masih dalam kandungan kondisi kesehatan dan gizi yang diberikan Ibu akan mempengarui pertumbuhan dan perkembangan anak.

Dalam literatur pendidikan dan psikologi, pertumbuhan (growth) meliputi kematangan, perkembangan dan belajar. Kematangan lebih bersifat biologis karena menunjuk pada proses intrinsik dari pencapaian tahap-tahap perkembangan anak, sedangkan perkembangan menunjuk kepada perubahan yang progresif pada organisme tidak saja secara fisik tetapi juga dalam segi fungsinya dan belajar sendiri merupakan aspek perkembangan yang menunjuk kepada perubahan perilaku sebagai hasil praktik dan pengalaman.

Pertumbuhan tidak saja menjadikan tubuh anak lebih besar secara fisik, tetapi struktur organ dalam dan otak pun turut meningkat. Pertumbuhan otak tersebut menyebabkan anak memiliki kemampuan yang lebih besar untuk belajar, mengingat dan berpikir. Karenanya peretumbuhan lebih bersifat kuantitatif sehingga lebih mudah untuk diukur sebaliknya perkembangan berkaitan dengan perubahan kualitatif dan kuantitatif. Ia dapat didefenisikan sebagai deretan progresif dan perubahan yang teratur dan koheren. Progresif menandakan perubahan terjadi secara terarah maju bukan mundur, sedangkan koheren dan teratur menunjukkan adanya hubungan nyata antara perubahan yang terjadi dengan apa yang terjadi sebelumnya.

Bila melihat berbagai defenisi di atas, secara samar terlihat bahwa sesungguhnya otak mempunyai peran penting dalam perkembangan anak. Dengan berkembangnya otak anak tentu akan memungkinkannya memiliki berbagai kecakapan hidup yang akan berguna bagi proses survive dan aktualisasi diri anak di kemudian hari. 
Kata brain dalam bahasa Inggris yang berarti otak berasal dari kata Anglo Saxon, braegen. Orang Yunani menyebutnya enkephalos dari kata encephalon yang kemudian digunakan sebagai istilah kedokteran untuk menyebut otak. Dalam Kamus Besar Bahasa Indonesia, otak diartikan sebagai kumpulan saraf-saraf yang menjadi isi kepala alat berpikir.

Mufidah (2014: 3) menyatakan bahwa otak manusia adalah massa protoplasma yang paling kompleks yang pernah dikenal di alam semesta ini. Otak mempunyai cara kerja yang sungguh menakjubkan. Struktur otak yang ada akan berpengaruh pada perilaku, metabolisme, pelepasan hormon dan aspek fisiologi tubuh lainnya. Struktur dan fungsi otalk terdiri dari:

1. Pangkal otak (disebut juga sebagai reptilian brain) terdiri dari: kerak dalam (pon dan system reticular) yang berfungsi untuk mengatur kehidupan, medulla-berfungsi mengatur organ-organ utama; tidur dan jaga (arousal), Serebelumkeseimbangan / pergerakan. Bagian otak ini bertanggungjawab atas fungsi-fungsi motor sensor yakni pengetahuan tentang realitas fisik yang berasal dari panca indra.

2. Otak bawah (system limbic) yang merupakan kendali untuk motivasi, emosi dan ingatan; terdiri dari thalamuspusat sensori/rangsangan, hipotalamus-mengatur suhu badan, lapar/dahaga, kegiatan system saraf, dan pusat kesenangan, amigdala-pusat keagresifan, dan hipokampuslokasi pembentukan ingatan. Bagian otak ini fungsinya bersifat emosional dan kognitif; yaitu menyimpan perasaan, pengalaman yang menyenagkan, memori dan kemampuan belajar. Selain itu sistem limbic juga mengendalikan bioritme seperti pola tidur, lapar, haus, tekanan darah, detak jantung, gairah seksual, temperature dan kimia tubuh dan system kekebalan. System limbic ini merupakan bagian yang penting dalam mempertahankan kehidupan manusia. Kenyataan bahwa bagian otak yang mengendalikan emosi juga mengendalikan semua fungsi tubuh menjelaskan mengapa emosi dapat secara langsung mempengaruhi kesehatan. System limbic adalah panel control utama yang menggunakan informasi dari indra penglihatan, pendengaran, sensasi tubuh, 
indra peraba sebagai inputnya. Kemudian informasi tersebut didistribusikan be bagian pemikir otak.

3. Otak luar (korteks cerebrum) - the thinking brain yang terdiri dari; korteks-lokasi kecerdasan, dan neokorteks mengatur penglihatan, pendengaran, percakapan, pemikiran dan reka cipta; terdiri dari beberapa bagian (lobes). Bagian otak ini merupakan tempat bersemayamnya kecerdasan. Bagian ini juga mengatur pesan-pesan yang diterima melalui penglihatan, pendengaran, dan sensasi tubuh. Proses yang berasal dari pengaturan ini adalah penalaran, berfikir secara intelektual, perilaku waras, bahasa, kendali motorik sadar, dan ideasi (penciptaan gagasan) non verbal.

Lily (2008: 25) menyebutkan Sistem saraf janin dan bayi berbeda dengan orang dewasa, baik struktur maupun fungsinya. Perkembangan otak janin pada beberapa minggu sampai 6 bulan pertama kehamilan, sangat pesat karena peningkatan jumlah sel otak yang menyebabkan kenaikan berat otak. Pada manusia bagian terbesar dari periode perkembangan pesat terjadi pada masa postnatal (setelah lahir) yang berlanjut sampai anak berusia 3 tahun.

Kecepatan berkembangnya otak pada periode ini dapat diamati dari cepatnya otak bertambah berat yaitu dari $400 \mathrm{gr}$ atau 25 persen waktu lahir menjadi hampir $3 x$ lipatnya atau 75 persen setelah tahun kedua. Myelinasi terjadi saat anak masih dalam kandungan dan berlanjut setelah kelahiran. Myelinasi jalan visual terjadi sesaat setelah kehiran hingga bulan pertama, sedangkan myelinasi auditori berlangsung hingga usia 4 atau 5 tahun dan beberapa aspek myelinasi lainnya pada masa remaja. Dalam dua tahun pertama juga terjadi peningkatan drastis hubungan sinapsis, yang diikuti oleh pemutusan secara bertahap di tahun pertengahan hingga akhir prasekolah.

Daerah-daerah otak tidak matang dengan serta-merta ketika baru lahir, myelinasi pada lobus frontal di tahun pertama memungkinkan anak memiliki kendali psikologis terhadap dirinya seperti aktivitas tidur dan gerakan refleks. Di usia 2 bulan, pusat kendali motoriknya berkembang hingga memungkinkannya secara tiba-tiba mampu mengenggam objek yang dekat dengannya, usia 4 terbentuk hubungan neural yang memungkinkan terbentuknya kedaalaman persepsi dan di bulan ke 12 pusat bicara anak mulai 
diseimbangkan sehingga memungkinkan berbagai keajaiban seperti pengucapan kata pertamanya. Myelinasi bagian otak yang berhubungan dengan perhatian yang terfokus tidak lengkap hingga usia 4 tahun. Antara umur 3-6 tahun, area lobus frontal tumbuh cepat yang menimbulkan kemampuan perencanaan, pengaturan tindakan baru dan kemampuan kosentrasi dan baru di usia 6 hingga masa puber, terjadi perkembangan lobus temporal dan pariental yang memainkan peran bahasa dan hubungan spasial pada anak.

Stimulasi lingkungan sangat diperlukan karena adaptasi otak dengan stimulus lingkungan inilah yang akan menimbulkan "dendritic sprouting", makin banyak anak diberi stimulus dengan lingkungan maka anak tersebut akan semakin cerdas. Jadi pada 2 tahun pertama merupakan kesempatan emas untuk bagi orangtua dan guru namun dengan adanya teori yang menyebutkan bahwa sel neuron dapat terus tumbuh sampai usia berapapun.

Menginjak usia sekitar sepuluh tahun misalnya, Sekitar separuh hubungan telah mati pada kebanyakan anak, tetapi masih meninggalkan sekitar 500 triliun yang akan bertahan sepanjang hidupnya. Hingga usia 12 tahun, Otaknya sudah dilihat sebagai spons super yang paling banyak menyerap sejak kelahiran hingga usia sekitar 12 tahun. Selama tahap ini dan khususnya di tiga tahun pertama; bahasa, dasar-dasar berpikir, tingkah laku, pandangan, karakteristik lain dan bakat diletakkan pondasinya. Maka kesempatan emas pun akan lebih terbuka untuk memberikan asupan dan stimulus yang tepat untuk otak anak.

Perkembangan otak banyak dipengaruhi oleh faktor genetik dan stimulasi lingkungan baik kualitas maupun kuantitas, hal ini menyebabkan keanekaragaman individual yang tidak identik. Periode perkembangan cepat dari otak ini merupakan peluang emas yang tidak boleh dilewatkan. Yang harus ditekankan adalah otak bayi menunggu pengalaman seperti rangkaian penglihatan, bau, suara, sentuhan, bahasa dan kontak mata untuk menentukan bagaimana hubungan antar neuron terbentuk.

\section{Brain Based Learning}

Brain based learning atau pembelajaran berbasis otak merupakan sebuah konsep untuk menciptakan pembelajaran dengan 
berorientasi pada upaya pemberdayaan potensi otak. Pada tahun 1970, Paul Mc.Clean mulai memperkenalkan konsep Triune theory Theory yang mengacu pada proses evolusi tiga bagian otak manusia. Dalam hipotesisnya, Mc.Clean menyatakan bahwa otak manusia terdiri dari tiga bagian penting: otak besar (neokorteks), otak tengah (system limbic), dan otak kecil (otak reptile) dengan fungsi masing2 masing-masing yang khas dan unik. Otak besar (neokorteks) memiliki fungsi utama untuk berbahasa, berfikir, belajar, memcahkan masalah, merencanakan dan mencipta. Kemudian, otak tengah (sistim limbic) berfungsi untuk interaksi interaksi social, emosional, dan ingatan Jangka panjang. Herman menuturkan bahwa otak kecil (otak reptile) sendiri menjalani fungsi untuk bereaksi, naluriah, mengulang, mempertahankan diri, dan ritualis (Nur Mufidah, 2014: 50).

Triune Theory merupakan sebuah temuan penting yang direspons secara positif oleh dunia pendidikan, terutama dalam kaitannya untuk mengembangkan sebuah strategi pembelajaran berbasis otak dan memberdayakan seluruh potensi diri siswa. Kecenderungan umum yang hadir di ruang kelas sekolah adalah terjadinya pembelajaran tradisional yang relative hanya memfungsikan otak kecil semata, dimana proses pembelajaran yang terjadi bersifat teacher centered dengan menjadikan siswa sebagai objek pembelajarandengan aktifitas utamanya untuk menghafal materi pembelajaran, mengerjakan tugas dari guru, menerima hukuman jika melakukan kesalahan, dan kurang mendapatkan penghargaan terhadap hasil kerjanya.

Brain based teaching and learning menyarankan bahwa proses pembelajaran berjalan sesuai dengan cara otak berfungsi. Otak dilahirkan untuk belajar dan menyimpan semua pembelajaran yang pernah terjadi dalam diri kita. Ia bisa memproses pengetahuan dengan berbagai cara, misalnya dengan menganalisis, menilai, menghakimi, membuat keputusan dan sebagainya. Dalam hal ini peran kita hanya menyediakan lingkungan yang sesuai untuk mendorong proses pembelajaran berjalan maksimal dan berkesan sesuai cara otak belajar.

Keseluruhan otak terlibat dalam proses belajar. Masingmasing bagian otak mempunyai syaraf tertentu dan mengatur tugas- 
tugas yang harus dilakukan dalam belajar. Tiga bagian otak tadi juga dibagi menjadi dua belahan kiri dan kanan, sering dikenal sebagai "otak kanan dan "otak kiri. Masing-masing belahan bertanggungjawab terhadap cara berfikir, dan masing-masing mempunyai spesialisasi dalam kemampuan-kemampuan tertentu.

Proses berfikir otak kiri bersifat logis, sekuensial, linier, dan rasional. Sisi ini sangat teratur. Walaupun dalam realitas, ia menafsifkan penafsiran abstrak dan simbolis. Cara berfikirnya sesuai untuk tugas-tugas teratur seperti ekspresiverbal, menulis, membaca, asosiasi auditorial, menempatkan detail dan fakta, fonetik serta simbolisme.

Cara berfikir otak kanan bersifat acak, tidak teratur, intuitif, dan holistic. Cara berfikirnya sesuai dengan cara-cara untuk mengetahui yang bersifat non verbal seperti perasaan dan emosi, kesadaran yang berkenaan dengan perasaan, kesadaran spasial, pengenalan bentuk dan pola, musik, seni, kepekaan warna, kreatifitas, dan visualisasi.

Dalam proses belajar di kelas, otak kiri menumpukan kepada pengetahuan atau fakta yang diicapkan guru, sementara otak kanan meneliti bagaimana pengetahuan itu diucapkan. Demikian juga, bila kita mendengar lagu, otak kiri akan meneliti seni kata lagu, sedangkan otak kanan memproses melodinya. Otak bawah atau system limbic juga menerapkan elemen emosi dalam pembelajaran. Secara langsung atau tidak langsung, keseluruhan otak kiri dan kanan terlibat secara aktif dalam pembelajaran. Oleh karena itu, jika ucapan atau perkataan digabungkan dengan music atau gambar, atau jika ucapan atau perkataan music atau gambar, atau jika perkataan diucapkan dengan emosi, ia akan lebih mudah diingat atau dipelajari.

Pembelajaran berbasis otak menerangkan pentingnya individu sebagai seseorang yang belajar dan individu sebagai seorang penterjemah makna dan pembuat keputusan dalam proses pembelajaran, baik ilmu yang diterjemah irasional dan logikal, atau dipengaruhi faktor social dan budaya yang membentuk ilmu itu sesuai interpretasinya terhadap pengalaman yang ada, pengalaman sebelum dan pengaruh-pengaruh lain. Oleh karena itu, menurut Crebbin (2000: 5): 
Learning is a personal, emotionally embedded process, in which tacit (conscious or subconscious) knowledge have the potential to impact on the multiple ways in which the students interpret information without any conscious awareness.

Brain based teaching and learning menawarkan sebuah konsep untuk menciptakan pembelajaran dengan berorientasi pada upaya pemberdayaan potensi otak siswa. Ada tiga strategi yang dapat dikemnagkan dalam implemensi brain based learning. Pertama, menciptakan lingkungan belajar yang menantang kemampuan berfikir siswa. Dalam setiap kegiatan pembelajaran guru pasti sering memberikan soal yang dikemas variatif dan seatraktif mungkin. Soal-soal ini memfasilitasi kemampuan berfikir siswa dari tahap pengetahuan (knowledge) sampai tahap evaluasi menurut tahapan berfikir berdasarkan taxonomy bloom. Pemberian soal ini agar siswa dapat terbiasa untuk mengembangkan kemampuan berfikirnya dalam kontaks pemberdayaan potensi otak siswa.

Kedua, menciptakan lingkungan pembelajaran yang menyenangkan. Howard Gardner dalam buku quantum learning karya De Porter, Bobbi,\& Mike Hernacki menyatakan bahwa seseorang akan belajar dengan segenap kemampuan apabila dia menyukai apa yang dia pelajari dan dia akan merasa senang terlibat di dalamnya.

Ketiga, Menciptakan situasi yang aktif dan bermakna bagi siswa (active learning). Siswa dirangsang melalui kegiatan pembelajaran untuk dapat membangun pengetahuan mereka melalui proses belajar aktif.

Caine dan Caine (2003: 4) menjelaskan 12 prinsip utama dalam brain based learning, yaitu:

1. Otak merupakan processor parrarel. Pikiran, perasaan, sifat bawaan, dan emosi saling berhubungan satu sama lain dan berinteraksidengan berbagai macam model informasi yang diterima otak

2. Pembelajaran perlu melibatkan keseluruhan proses fisiologi.

3. Mencari pengertian atau pemahaman adalah keinginan awal manusia.

4. Pemahaman terjadi apabila pola/corak dapat dibentuk. Pencarian makna terjadi dengan berpola. Berpola disinilebih 
dimaksudkan pada pengorganisasian dari pengkategorian informasi.

5. Emosi penting dalam membentuk pola/corak. Emosi merupakan salah satu bagian penting dalam pembentukan pola dalam otak, kita tidak bisa memisahkan emosi dengan kemampuan otak dalam berfikir secara kognitif, karena kedua hal tersebut merupakan factor yang saling berhubungan. banyak penelitian tentang otak yang menyatakan bahwa tidak ada ingatan tanpa emosi. Emosi merupakan sesuatu hal yang membuat kita lebih semangat belajar.

6. Otak bisa memproses keseluruhan dan sebagian pengetahuan sekaligus. Dalam pembelajaran perlu melibatkan kedua belah otak secara bersamaan.

7. Pembelajaran melibatkan penumpuan perhatian kepada lingkungan peripheral. Belajar melibatkan perhatian yang dipusatkan pada persepsi sekitar.

8. Pembelajaran melibatkan proses-proses sadar dan tanpa sadar.

9. Terdapat dua jenis ingatan, yaitu hafalan dan spasial.

10. Belajar merupakan sebuah perkembangan.

11. Pemahaman terbentuk jika fakta tersimpan dalam ingatan spasial. Pembelajaran bisa diperkuat jika kita menghadapi tantangan dan menghalang ancaman belajar.

12. Setiap otak adalah unik dan setiap individu berlainan. Hal ini terlihat dari gaya belajar dan cara seseorang menyimpan informasi dalam sebuah pola.

Uriain di atas memberikan pemahaman yang jelas tentang proses pembelajaran berasaskan otak. Model pembelajaran ini terbukti menarik untuk meningkatkan penguasaan ilmu pengetahuan di samping memastikan perkembangan potensi menyeluruh dikalangan siswa. Hal ini sesuai dengan pendapat yang dikemukakan oleh Clemons yang menyatakan "kunci sukses dalam pengaplikasian pembelajaran berbasis otak (brain-based learning) untuk setiap orang yang dilibatkan dalam proses pembelajaran dan dalam lingkungan brain-based learning, material dan pengajaran harus berpusat pada siswa dan disampaikan dengan menyenangkan, bermakna untuk diri siswa” (Jensen, 2011: 9). Melalui pembelajaran yang demikian, 
maka siswa akan termotivasi mengikuti pembelajaran, memiliki pemahaman konsep yang mendalam, dan mengembangkan keterampilan berpikirnya.

\section{Otak dan proses belajar}

Pendidikan anak usia dini harus sangat diperhatikan. Proses belajar sangat menentukan keberhasilan anak dalam belajar. Factor yang sangat berpengaruh dalam pembelajaran anak usia dini selain orang tua adalah guru di sekolah. Seorang pendidik tentu lebih baik daripada seorang pengajar. Guru mendidik murid mempunyai beban moralitas dan nilai-nilai khusus yang harus dia tanamkan. Seorang anak hasil diajar dan dengan anak hasil dididik akan berbeda. Anak yang diajar ilmu matematika hanya bisa menirukan cara gurunya memecahkan soal matematika tetapi anak yang dididik matematika tidak hanya memcahkan perhitungan yang rumit namun paham aspek dan nilai-nilai yang harus dia pertanggungjawabkan terhadap hasil perhitungannya. Kemudian seseorang yang melakukan penggelapan pajak yang harus disetorkan kepada Negara jelas adalah hasil dari ilmu ajaran matematika. Mereka tak menghiraukan apakah perhitungan itu akan menimbulkan masalah pada lingkungan atau tidak. Sebaliknay anak didikan ilmu matematikan akan memperhatikan rambu-rambu nilai moralitas dalam penerapan ilmunya (Yulisardi, 2010: 20). Otak memiliki aneka kemampuan dalam berfikir, memutuskan, berkreasi, berbicara, pemahaman bahasa, berhitung, berfikir yang lebih rumit, orientasi atau pengenalan posisi diri dalam ruang (Arman, 2010:15). Orangtua dan lingkungan mempunyai andil besar dalam tumbuh kembang otak serta pengenalan dan pengembangan bakat anak.

Suatu konflik yang rumit dapat terjadi bila orang tua tidak memahami dalam meledakkan semangat belajar putra-putri mereka yaitu tidak bersikap realistis. Orang tua harus realistis dalam menetapkan harapan dan keinginannya. Adalah realistis bila seorang ayah yang berprofesi sebagai seorang dokter dan ibu juga seorang dokter berharap si anak kelak menjadi dokter. Mengapa? Karena bakat-bakat genetik itu sudah ada, aneka rangsangan di dalam lingkunagn itu juga sudah tersedia. Aneka buku textbook kedokteran dan aneka peralatan kedokteran untuk mengobati orang bisa menjadi alat perangsang motivasi semangat anak dalam mencapai cita- citanya. 
Di samping itu, orang tua juga harus memberi contoh menikmati suatu keberhasilan. Belajar adalah suatu aktifitas yang harus dilakukan oleh manusia untuk mencapai tingkatan yang lebih tinggi. Di dalam ajaran agama islam disebutkan kalimat: "adakah sama orang yang mengetahui dengan orang yang tidak mengetahui?” Orang tua harus bisa menunjukkkan kepada si anak bahwa menjadi tahu itu menyenangkan dibandingkan dengan orang yang tidak mengetahui. Seorang anak yang menampakkan bakat-bakat kesenangannya dalam merawat tanaman dan orang tua berharap si anak menjadi ahli pertanahan, maka sang ayah sah-sah saja bila si ayah merangsang otak si anak dengan kegiatan merawat tanaman. Orang tua memberikan suatu contoh bagaimana tanaman buah yang dipelihara sejak dari pembibitan bisa menghasilkan buah. Bila tanaman buah itu berhasil berbuah ekspresi orang tua harus tampak.

\section{Motivasi Belajar dan Sirkuit papetz}

Ada keterkaitan antara motivasi dan struktur dari otak. Motivasi dapat mempengaruhi anak dalam belajar sehingga berpengaruh dengan prestasi yang dihasilkan. Sartain mengatakan bahwa motivasi adalah suatu pernyataan yang kompleks di dalam suatu organisme yang mengarahkan tingkah laku terhadap suatu tujuan (Purwanto, 2007: 61). Tujuan adalah yang membatasi atau menentukan tingkah laku organisme itu. Peranan motivasi dalam belajar sangat besar pengaruhnya untuk menentukan arah belajar dan tujuan belajar. Hal ini didukung oleh pendapat Sardiman (2001: 85) yang menyatakan "Intensitas motivasi seseorang siswa akan sangat menentukan tingkat pencapaian prestasi belajarnya”.

Motivasi belajar dapat digolongkan dalam dua kategori yaitu motivasi instrinsik dan motivasi ekstrinsik. Sehubungan dengan hal tersebut (Sardiman, 2001: 89) menyatakan bahwa: "motivasi instristik adalah motif-motif yang menjadi aktif atau berfungsinya tidak perlu dirangsang dari luar, karena dari dalam diri seseorang sudah ada dorongan untuk melakukan sesuatu, sedangkan motivasi eksrinsik adalah motif-motif yang aktif dan berfungsinya karena adanya perangsang dari luar".

Selanjutnya di dalam otak terdapat sirkuit ini menjelaskan bahwa terdapat suatu keterkaitan antara emosi dengan kemampuan 
menghapal. Seseorang yang dalam keadaan emosi gembira, bila mempelajari suatu topik yang tentunya menarik, maka memori akan terekam dengan sangat kuat, demikian pula seseorang yang pernah dimarahi oleh guru matematika tanpa paham makna guru itu marah, akan merekam peristiwa itu dengan berakibat akan terjadi suatu kesualitan dalam mempelajari ilmu matematika karena emosi yang tidak mendukung.

Dengan melihat pernyataan tersebut dapat ditarik kesimpulan bahwa begitu penting peran dari guru, orang tua dan lingkungan dalam pendidikan. Untuk menciptakan dan meningkatkan motivasi belajar pada anak harus ada koordinasi yang kuat diantara ketiga unsur tersebut sehingga anak dapat membangun emosinya dengan baik sehinggga dapat membangkitkan motivasi belajarnya. Suasana emosi yang menyenangkan dapat menghantarkan anak mendapatkan hasil yang maksimal. emosi anak harus keadaan senang minimal stabil dalam mempelajari suatu mata pelajaran.

Unsur dalam sirkuit papetz ada dua yaitu emosi dan memori. Memori ini ada dua jenis secara garis besar. Memori semantik (katakata orang, namun peristiwa) dan memori procedural (bersifat refleks) misalnya kecepatan mempelajari suatu ketrampilan. Potensi setiap anak berbeda. Memori semantik menonjolkan pada profesiprofesi yang tidak memerlukan ketrampilan tangan yang tidak terlalu banyak pemikiran, yaitu scientist sedangkan bakat dalam menyimpan memori prosedural lebih menonjol yaitu atlit, misalnya atlit panahan, senam, bela diri yang memerlukan reflex (Yulisardi, 2010: 115).

Dengan mengetahui dari fungsi-fungsi neuron pada otak, orang tua dapat mengarahkan dan mengembangkan bakat dan potensi yang ada pada anak. Dengan kebiasaan dan arahan serta pemenuhan fasilitas dapat menunjang potensi anak yang sangat hebat. Untuk mendapatkan hasil yang maksimal perlu adanya motivasi yang bisa membangkitkan anak mempunyai emosi yang baik sehingga dapat belajar dengan enjoy tidak dengan pemaksaan. Pembelajaran yang menyenagkan diantara dengan menggunakan game atau permaiann juga dapat menunjang kecerdasan anak. Sebagai Orang tua dan pendidik harus bisa menerapkan permainan sebagai stimulus yang tepat guna mendapatkan hasil yang maksimal dalam menunjang prestasi anak. 


\section{Smart Game}

Permainan anak kecil berkontribusi pada perkembangan fungsi otak paling dasar mereka: kemampuan mengendalikan prilaku mereka sendiri untuk mencapai satu tujuan. Kemampuan ini mendasari keberhasilan di banyak bidang yang diindahkan orangtua, mulai sosialisasi sampai tugas sekolah. Sirkuit saraf yang bertanggungjawab itu adalah beberapa bagian otak yang paling lambat berkembang. Ini bisa dikonfirmasi oleh setiap orang tua anak berusia dua tahun.

Berdasarkan penelitian dari dr. Arman Yuliardi bahwa permainan tetris merupakan permainan yang murah namun vital bagi otak. Permainan ini melatih fungsi spasial atau penguasaan lapangan pandang dan daya perkiraan yang tajam.

Pada awal permainan tetris memerlukan konsentrasi otak besar yang tinggi, namun semakin permainan berlanjut dan daya latihan pemain sudah demikian tinggi maka permainan akan semakin cepat dan pemain konsentrasinya akan menurun, namun tetap bisa mencetak skor yang tinggi. Hal ini dikarenakan pemain bekerja memakai refleks otak kecil. Dalam dunia ilmu saraf yang membahas kecerdasan otak dinamakan "little brother teach big brother".

Permainan tetris dapat mengaktifkan serebelum (otak kecil) anak dengan latihan-latihan koordinasi antar otak besar dengan kecil. Dengan bermain tetris anak dapat dilatih selanjutnya dengan hal-hal yang baik dengan latihan koordinasi antara kecepatan berfikir dengan reflex bersikap.

Menurut Arman, acara cerdas cermat juga dapat melatih hubungan otak kecil. Ketika peserta sudah mendapat konsep jawaban harus segera dilaksanakan dengan cepat dengan cara menekan tombol bel. Acara cerdas cermat yang sarat dengan hal-hal akademis dapat melatih anak dalam mengambil keputusan cepat tepat dengan segala resikonya dan sekaligus melatih kecepatan aplikasi teori dengan praktek. Namun sayang acara cerdas cermat sudah tidak ada lagi di stasiun tv sebagai hiburan edukatif.

Melatih memori procedural dalam porsi merevolusi cara belajar anak adalah penting. Mekanisme reflek diperlukan untuk melatih ketepatan berlogika dalam berdebat ketepatan pemilihan 
kata-kata saat dicecam pertanyaan disaat ujian lisan, reflex menolak saat anak di ajak teman-teman melakukan perbuatan yang tidak terpuji, reflex mengambil posisi hormat (terlebih orang jepang dan sikap ngapuran cay atau telapak tanagan beri hormat pada orang jawa) semua itu tak lepas dari fungsi serebelum.

Dari proses tersebut diatas bisa kita generalisasikan bahwa pembelajaran Brain based learning merupakan suatu pola pembelajaran yang berbasis otak dengan mengembangkan potensi otak dengan proses belajar yang menyenangkan dan lingkungan yang nyaman.

\section{Simpulan}

Dari hasil kajian diatas didapatkan bahwa Brain based learning atau dalam istilah lain biasa disebut pembelajaran berbasis otak merupakan sebuah konsep pembelajaran yang berorientasi pada pemberdayaan potensi otak. Dalam prosesnya berjalan sesuai dengan cara otak berfungsi mulai dari memproses pengetahuan dengan jalan menganalisis, menilai, menghakimi, membuat keputusan dan sebagainya. Keseluruhan bagian-bagian dari otak terlibat langsung dalam proses belajar-mengajar.

Otak sendiri terbagi menjadi beberapa bagian diantaranya otak kecil, otak kiri, dan otak kanan. Bagian yang paling sering diakses manusia yaitu otak kanan dan otak kiri. Hubungannya dengan proses belajar, cara berfikir otak kanan sesuai dengan caracara untuk mengetahui yang bersifat non verbal seperti perasaan dan emosi, kesadaran yang berkenaan dengan perasaan, kesadaran spasial, pengenalan bentuk dan pola, musik, seni, kepekaan warna, kreatifitas, dan visualisasi.

Sedangkan otak kiri mengumpulkan kepada pengetahuan atau fakta yang diucapkan guru, sementara otak kanan meneliti bagaimana pengetahuan itu diucapkan. Demikian juga, bila kita mendengar lagu, otak kiri akan meneliti seni kata lagu, sedangkan otak kanan memproses melodinya. Otak bawah atau system limbic juga menerapkan elemen emosi dalam pembelajaran. Secara langsung atau tidak langsung, keseluruhan otak kiri dan kanan terlibat secara aktif dalam pembelajaran. Oleh karena itu, jika ucapan atau perkataan 
digabungkan dengan music atau gambar, atau jika ucapan atau perkataan music atau gambar, atau jika perkataan diucapkan dengan emosi, ia akan lebih mudah diingat atau dipelajari.

Brain based teaching and learning memberikan gagasan baru bagaimana menciptakan proses pembelajaran yang menekankan optimalisasi potensi otak siswa. Beberapa strategi yang dapat dipakai diantaranya ada tiga : Pertama, menciptakan lingkungan belajar yang menantang kemampuan berfikir siswa. Kedua, menciptakan lingkungan pembelajaran yang menyenangkan. Dan yang Ketiga, Menciptakan situasi yang aktif dan bermakna bagi siswa (active learning). Siswa dirangsang melalui kegiatan pembelajaran untuk dapat membangun pengetahuan mereka melalui proses belajar aktif.

Hal tersebut diatas memberikan pemahaman yang jelas tentang proses pembelajaran berasaskan otak. Model pembelajaran ini terbukti menarik untuk meningkatkan penguasaan ilmu pengetahuan di samping memastikan perkembangan potensi menyeluruh dikalangan siswa. Melalui pembelajaran yang demikian, maka siswa akan termotivasi mengikuti pembelajaran, memiliki pemahaman konsep yang mendalam, dan mengembangkan keterampilan berpikirnya. Yang tidak kalah penting juga, pentingnya peran tripusat pendidikan yang meliputi guru, orang tua dan lingkungan dalam pendidikan, maka dalam menciptakan dan meningkatkan motivasi belajar pada anak harus ada koordinasi yang kuat diantara ketiga unsur tersebut sehingga anak dapat membangun emosinya dengan baik sehinggga dapat membangkitkan motivasi belajarnya. 
Chamidiyah

\section{DAFTAR PUSTAKA}

Ahmad, Nur. 2014. Menggali Potensi Kecerdasan Anak Melalui Pendekatan Spiritual. Jurnal Thufula, journal of Preschool Education.Volume Juli-Desember. Jurusan Tarbiyah STAIN Kudus.

Buzan, Tony. 2002. Use Your Perfect Memory. Teknik Optimalisasi Daya Ingest. Temuan terkini Tentang Otak Manusia. Terjemahan basuki Hari Winarno. Ikonterelitera. Yogyakarta.

Caine, R. N., \& Caine, G. (2003). 12 Brain/Mind Learning Principles In Action. The Eldbook for Making Connections, Teaching And The Human Brain. Thousand Oaks, CA: Corwin Press.

Fathurrahman, M. dan Sulistiyorini. 2012. Belajar dan Pembelajaran. Yogyakarta: Sukses offset.

Hamalik, Oemar. 2008. Pendidikan Guru Berdasarkan Pendekatan Kompetensi. Jakarta: PT. Bumi Aksara.

Hurlock, Elizabeth B. 1978. Child Development International Student Edition. Mcgraw Hil.

Megawangi, dan Williams. 2011. Dampak Pendidikan Karakter Terhadap Akademi Anak: http://pondokibu.com/parenting/ pendidikan-psikologianak/dampak-pendidikan-karakterterhadap-akademi-anak/ (diakses 21 Juni 2015)

Mufidah, Luk luk Nur. 2014. Brain Based Teaching.Yogyakarta: Sukses offset.

Purwanto, M.N. 2007. Psikologi Pendidikan. Bandung: Remaja Rosdakarya.

Salim, Nibras Or dkk.2009. Acuan Menu Pembelajaran Pada Pendidikan Anak Usia Dini. Jakarta: Direktorat Pendidikan Anak Usia Dini.

Sardiman, A.M. 2001. Interaksi dan Motivasi Belajar Mengajar. 
Jakarta: Rajawali Pers.

Sidiarto, K \& Lily, D.S. 2008. Belajar \& Pola Pikir Berbasis Mekanika Otak (Whole-Brain Thinking) Jakarta: UI Press.

Wijana, Widarmi D. dkk. 2008. Kurikulum Pendidikan Anak Usia Dini. Jakarta: Universitas Terbuka.

Yulisardi, Arman. 2010. Merevolusi Cara Belajar Anak Melaluli Aktivasi Sirkuit Otak. Jakarta: Generasi Cerdas. 
Chamidiyah

halaman ini bukan sengaja dikosongkan 